Article

\title{
Can Pop Culture Allay Resentment? Japan's Influence in China Today
}

\author{
Yuqing $\mathrm{Wu}$ \\ Department of Sociology, Yale University, USA; E-Mail: dorothy.wu@yale.edu
}

Submitted: 30 January 2021 | Accepted: 27 May 2021 | Published: 5 August 2021

\begin{abstract}
In China, despite the traumatic collective memory relating to militaristic Japan during World War II, an increasing number of Chinese young adults have developed an obsession with Japanese culture, due to its export of anime, movies, pop music, and other popular culture. Based on interviews with 40 Chinese and Japanese young adults, this work examines how contemporary pop culture and historical war memories related to Japan influenced Chinese young adults, who had to reconcile their contradictory sentiments toward the Japanese government, people, and culture. The success of Japanese pop culture in China also shows how the allegedly apolitical, virtual sphere of entertainment has helped build Japan's soft power through shaping a cool image of Japan in Asia and worldwide.
\end{abstract}

\section{Keywords}

China; East Asia; Japan; national image; pop culture; soft power

\section{Issue}

This article is part of the issue "Complexity, Hybridity, Liminality: Challenges of Researching Contemporary Promotional Cultures," edited by lan Somerville (University of Leicester, UK) and Lee Edwards (London School of Economics and Political Science, UK).

(C) 2021 by the author; licensee Cogitatio (Lisbon, Portugal). This article is licensed under a Creative Commons Attribution 4.0 International License (CC BY).

\section{Introduction}

China today occupies the center of global attention as a rising power that may challenge the US-centric world order. With substantial economic and military strength, China nonetheless does not evoke either admiration or trust internationally (Shambaugh, 2015). Ever since 2004, the Chinese Ministry of Education has been trying to build Confucius Institutes to promote Chinese language and culture globally (Hartig, 2012). Since 2007, Beijing has invested billions of dollars into building 'the Chinese dream' and 'the Asia-Pacific dream' (Shambaugh, 2015, p. 100). But still, China's image remains mostly negative, especially among the wealthier parts of the world (Silver et al., 2019). Apparently, what China lacks is not hard power that can scare people away but the cultural influence to convincingly tell its own side of the story. In other words, China is in shortage of soft power-the persuasive approach to exert influence without force (Nye, 2012).

China's neighbor Japan, in contrast, has questionable hard power but a very appealing contemporary culture. A defeated country of WWII, Japan left unresolved scars among its many Asian neighbors. Postwar Japan also does not have an autonomous military due to American occupation (Schaller, 1985). Despite its militaristic past and a continued lack of apology deemed acceptable by the countries it victimized (Qiu, 2006; Ward \& Lay, 2016), contemporary Japan is nevertheless widely acknowledged to be "one of the world's leading diplomatic, cultural and soft power players" (Burney \& Donaldson, 2018).

Particularly in China, despite the institutionalized effort to preserve the traumatic memory through history textbooks and anti-Japan war dramas, an increasing number of Chinese young adults have developed an obsession with Japanese culture, due to its export of anime, movies, music, and other pop culture. This sense of affiliation with the non-serious, apolitical sphere of Japanese culture, as my article will later show, contributes to a political outcome that the Japanese government desires: A favorable perception of Japan as an advanced, attractive, and innocuous country-the opposite of what it once was. As pop culture serves as an 
important cultural repertoire for young people's selfidentification and socialization (Duff, 2002), we cannot help but wonder, what if such repertoire comes from a foreign country with whom your own country has a disturbing history?

Nye first coined the term 'soft power' in 1990 (Nye, 1990a). By far, soft power has been mostly theorized in political sciences (Ang et al., 2016; Holm, 2016; Nye, 1990a) and understood via the macro lenses of foreign investment, education, developmental aid, public policy, and ideology (Holm, 2016). In Nye's original discussion of soft power, he also did not give much weight to the commercial entertainment sphere but placed much more importance on national values and political ideologies (Nye, 1990b). Likewise, past scholars have mostly attributed China's soft power failure as China's fundamental lack of attractive political values (Paradise, 2009).

The overt emphasis on political values, however, ignores the fact that people's trust in political institutions has been decreasing, and they increasingly seek meanings and identifications in consumption culture, entertainment industry, and everyday life (Cronin, 2018). Focusing heavily on the political realm also renders the building of soft power susceptible to accusations of propaganda, brainwashing (Belmonte, 2013; Snow \& Taylor, 2006), verbal fighting (Mattern, 2005), and America-centrism (Hayden, 2012). Via interviews with 20 Chinese young adults as my main focus and interviews with 20 Japanese young adults as a comparison, my article offers a sociological conceptualization of soft power via a micro, cultural lens with two specific goals: (1) contrasting the national images of China and Japan; and (2) understanding this contrast, especially the success of Japanese pop culture which occurred even while Chinese young adults had to reconcile their attraction to Japanese culture with historical resentment. My analyses demonstrate the political effect of the apolitical, entertainment realm of popular culture, and how favorable sentiments toward a country can develop despite political resentment.

\section{Japan: Small Brother, Cruel Invader, or Aesthetic Symbol?}

The contact between China and Japan can be traced back to about 2,000 years ago in $A D 57$, when the emperor of the Han dynasty gave a golden seal to Japan. During China's prosperous Sui (隋) and Tang (唐) dynasties (AD 581-907), Japan sent students and imperial embassies to China to learn about state-building and brought back the Chinese writing system, bureaucratic structure, art style, and customs, as well as philosophical thoughts.

In 1839, the opium war between China and Great Britain signaled the beginning of ' 100 years of humiliation' of modern China by various invasions, exploitation, and colonial activities from not only Western Imperials but also Japan, a 'small brother' in China's perspective.
In 1894, Japan won the First Sino-Japanese War, and during WWII, among many of Japan's atrocities in Asia was the Nanjing Massacre, a six-week killing and raping spree which started December 13,1937, and led to the death of more than 300,000 Chinese citizens, according to Chinese official records (Liu et al., 1997).

The eighth-grade Chinese history textbook (Institute of Curriculum and Textbook, 2009) does not portray the Nanjing Massacre with mere descriptive texts-the time, the location, and the impact-but also pictures of the scalps of Chinese people clumping together like a mountain; the smiles of Japanese soldiers when they pierced through pregnant women's wombs to stab the baby; and the game played by Japanese soldiers to see who could kill the most Chinese in one day. Images, with their unique suggestibility and internal logic, shrink and intensify any temporal sequence to moments and easily provoke emotions (Alexander et al., 2012). For every 12 or 13-year-old Chinese middle school student, images from the textbook are routes of references and totems of causes from which they construct a sense of the past (Sontag, 2004).

The twenty-first-century China-Japan relationship remains contentious with: (1) Japan's textbook controversy (Gries et al., 2009; Qiu, 2006); (2) Japanese politicians' frequent visits to Yasukuni Shrine (a memorial for dead Japanese soldiers, many of whom were classed as war criminals; Qiu, 2006); as well as (3) territorial disputes, such as those over Diaoyu/Senkaku islands. Nevertheless, political conflicts merely serve as one source of Chinese people's perceptions of Japan. Ever since the 1990s, the rise of Japanese pop culture has established Japan as a major pop culture export country. Soap operas such as Tokyo Love Story and Long Vacation have achieved tremendous popularity in China, South Korea, and Thailand (Leung, 2004). In Taiwan, after the removal of the ban on broadcasting Japanese drama and songs in 1993, demand exploded (Iwabuchi, 1998; Yueh, 2016) to the extent that the term 'hari' was invented to describe the booming Japan mania (Lee \& Han, 2013). In Thailand, chains of Japanese restaurants and fashion stores mushroomed. At a glance, teenage shoppers "look as though they have popped out of Japanese fashion magazines" (Siriyuvasak, 2004, p. 184). At the same time, Thai youths' memory of the Japanese invasion in the 1940s was fading. Few could describe exactly what had happened, and in their everyday life, Japanese pop culture provided an important source to find, express, and live their self-identities (Siriyuvasak, 2004 , p. 197). Bilibili, one of the biggest video platforms in China and what is now recognized as 'China's YouTube,' was initially founded as a fandom community for a virtual Japanese character Hatsune Miku. Even today, most videos on this site theme around Japanese animation, comics, and games.

It is, therefore, no surprise that today, the information and the media sector is the biggest contributor to Japan's GDP. As an 878-billion-dollar industry that 
constitutes $9.6 \%$, the information and the media sector create profits surpassing business (9.3\%), real-estate (7.5\%), and healthcare (7.2\%; Ministry of Internal Affairs and Communications, 2018).

Given Japan's image jump from Samurai to 'cute,' philosopher Simon May (2019) points out that in contrast to Germany's unambivalent apologetic attitudes about WWII, Japan, with the elusiveness of cute, manages to avoid direct answers to questions of morality, responsibility, and sincerity. To other Asian nations, contemporary Japan is both 'one of us' - a positive, normative model for nation-building (Avenell, 2013)-and an 'other' to be wary of. In fact, Japan's national identity has always existed in a triad with 'the inferior Asia' and 'the advanced West' (Iwabuchi, 2002, p. 7; Tanaka, 1995). 'The inferior Asia' casts Japan's past and stands in contrast to Japan's progress in emulating the West (Takeuchi, 1993). In contrast to Japan's cultural power, China had not exported much of its cultural content. The import and export of mass media between China and Japan is highly unbalanced (Figure 1).

This unbalance might explain the survey result by Japan's The Genron NPO (2019), where the Chinese views toward Japan had been continuously improving after the trough of the Diaoyu/Senkaku Islands dispute in 2013, as shown in Figure 2. By 2019, about half of the Chinese people surveyed viewed Japan favorably, while the Japanese views toward China had consistently been

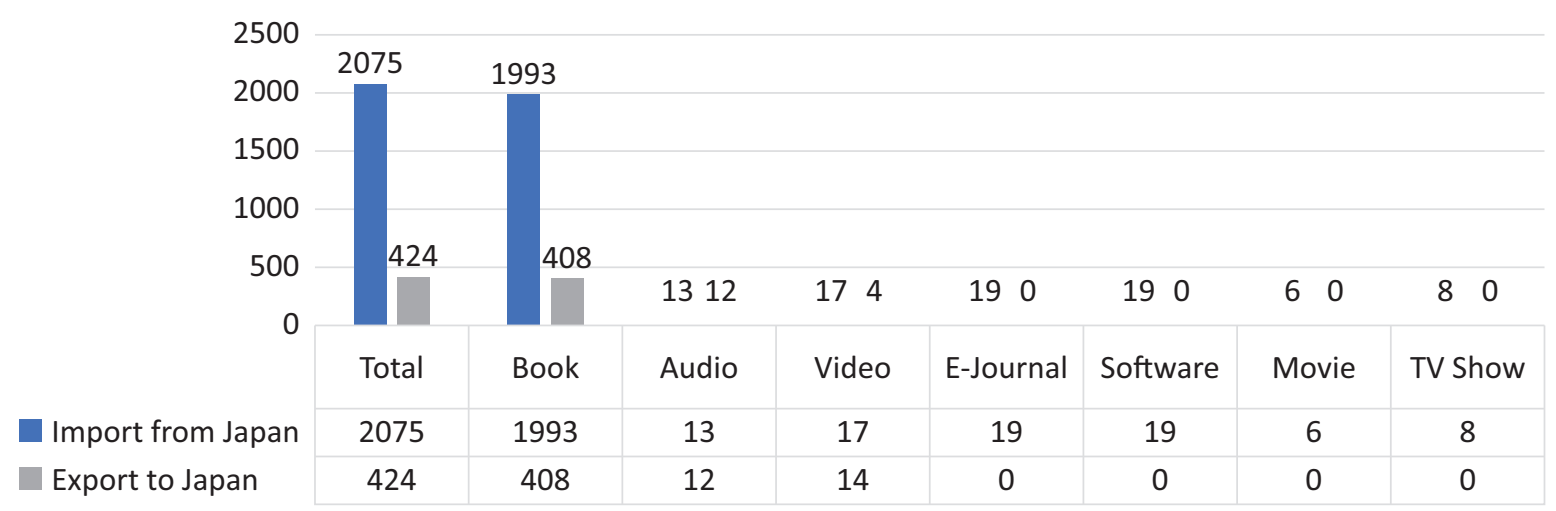

Figure 1. Copyrights import and export by media genre in China 2018. Note: Unit = piece. Source: National Bureau of Statistics of China (2019).

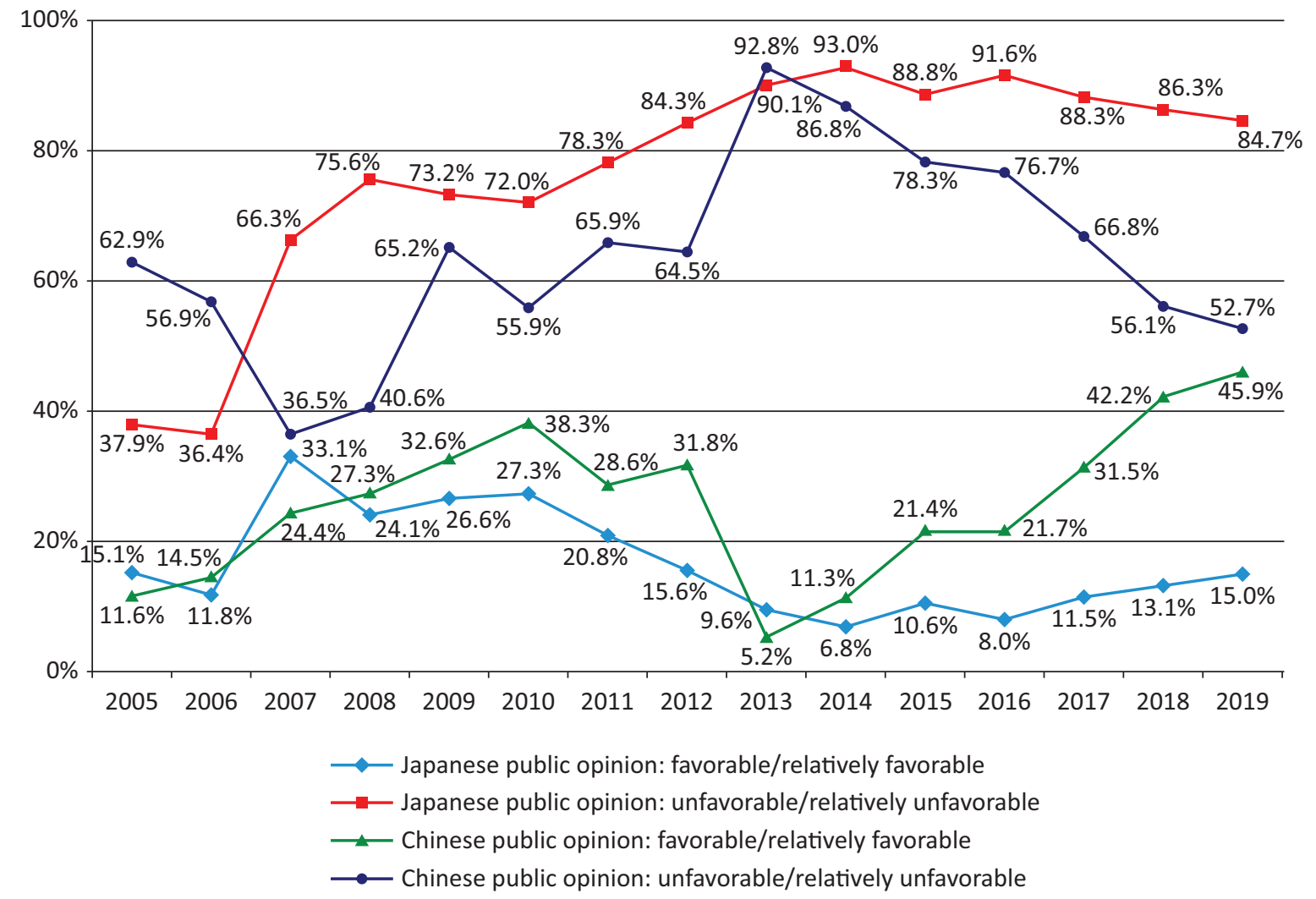

Figure 2. Genron NPO Japan-China Public Opinion Survey, 2005-2019. Source: The Genron NPO (2019). 
unfavorable. Nonetheless, another survey conducted by Pew Research Center in 2016 showed that the Chinese views toward Japan were equally unfavorable. Only $14 \%$ of the Chinese respondents viewed Japan favorably, and $90 \%$ of the Chinese respondents still believed Japan had not apologized enough, compared to only $11 \%$ of the Japanese respondents who viewed China favorably.

Therefore, findings in different national public surveys tend to vary. In addition, in Lee's interviews with Taiwanese young adults on their impressions toward Japan, she observed a flexible switch of persona between the (private) fan and the (public) nationalist (Lee \& Han, 2013). Switch of persona helps resolve contradictory sentiments by separating entertainment from politics, and personal fascination from the nationalistic norm. It also exposes the risk of public surveys only capturing the nationalistic, public side of respondents. Therefore, the interview data from my study can further explain the potential inconsistency and add depth to the survey results.

\section{Methods}

My study draws on interviews with 40 participants in total: 20 from China and 20 from Japan, all aged 18-30 and college-educated. The gender distribution is fairly balanced in both the Chinese $(M=9)$ and the Japanese sample $(M=8)$. Interviews with Chinese participants were conducted in Chinese, and those with Japanese participants were conducted in Japanese or English. All interviews were conducted between August 2019 and August 2020.

The Chinese sample consists of a convenience sample selected based on a knowledge of their different attitudes toward Japan (antagonistic, uninterested, interested). I intended to collect a sample with various attitudes toward Japan as opposed to a volunteer sample, as those attracted would tend to already have strong opinions toward Japan and thus leave out the uninterested respondents. 10 out of 20 Chinese participants can be characterized as more cosmopolitan, as they had the experience of studying abroad either short-term or long-term in places such as the US, Canada, or Europe. The other half did not have much experience abroad, attending colleges of varying levels of prestige in China. 5 out of the 20 respondents had been to Japan in the past, and two of them had had an experience of living or studying in Japan for two months and one year, respectively.

The Japanese sample consisted of 5 college students in the US and 15 college students in Japan ( 8 from Tokyo and 7 from Kyoto). Students came from colleges of varying levels of prestige and were recruited via snowball sampling. 3 research assistants located in Japan helped me recruit and conduct the 12 interviews. 7 out of 20 of the Japanese participants can be characterized as more cosmopolitan, with the experience of having studied in the US or Australia, and the rest had never been abroad. 4 out of the 20 respondents had been to China, and one of them had had the experience of living in China for about two months.

The limitations of my sample need to be noted, as 20 young people from each country can hardly be representative of the whole young population, even given the efforts made to ensure diversity. The point, however, is not to provide a quantitative opinion polling but to probe the reasons why young people may feel a certain way toward the country of interest, as well as the sources of information that may have prompted them to do so.

Each interview is semi-structured with 18 prepared questions and lasted on average for about an hour. Interview questions are largely comprised of three parts. In the first part (questions 1-5), participants are asked about their general impressions of the country of interest as a political entity, such as what they think of upon hearing its name, the adjectives they would use to describe it, and what they like and dislike about it. The second part (questions 6-8) tries to prompt participants to address the country as an aesthetic product, by asking about their experiences with the country's pop culture and travel experiences. The third part (questions 10-15) prompts participants to give their impressions of various other aspects of the country, such as its people, government, culture, food, sometimes with scenario questions such as "How do you feel when you see a Japanese person on the street in China," or "How do you feel when seeing the Japanese team in the Olympics." The point is to get a comprehensive picture of a respondent's sentiments toward different aspects of the country, which may be congruent or incongruent. Finally (questions 16-18), respondents are asked about their knowledge and views toward WWII, in terms of their own country and the target country.

During each interview, the interviewer typed down notes while the interviewee was speaking. Everything was also audio-recorded and transcribed afterward. Participant information and answers were documented in a spreadsheet, and all interview transcripts were stored, coded, and analyzed in NVivo.

\section{Results}

\subsection{Scratching the Surface: General Impressions}

Most Chinese respondents reported their impressions of Japan as 'neutral' or 'favorable.' In contrast to a 1996 survey in which $84 \%$ of the Chinese respondents gave the 'Nanjing Massacre' as their most immediate association upon hearing the word 'Japan' (Qiu, 2006), in my interviews, only two interviewees mentioned Japan's relationship with China as their immediate impression, and half of the Chinese respondents said 'anime.'

Another common association was Japan's aesthetic aspects, such as its fashion style (suits, uniforms, Lolita), aesthetic symbols (Fuji Mountain and cherry blossom), and the fact that Japan is a good tourist spot for shopping. Respondents frequently cited the beautiful scenery, architecture, and fashion as reasons for their 
favorable views toward Japan. Besides, almost every Chinese respondent talked about Japan's status as a developed country to explain their favorable viewsspecifically-Japan's high standard of living, its polite citizens, advanced technology, clean streets, and environmental awareness. Good preservation of traditional culture and vibrant contemporary anime industry were also two important reasons for favorable views:

I think [Japanese people] are very polite. They like to simplify complicated questions, which is similar to my personality - I am a minimalist. I am very curious about Japan. I hope to work there sometime in the future. I don't know why but I have the impressionmaybe from Japanese dramas-that their buildings and decorations have a good style-simple and useful. I also like their food. They respect the natural taste of the food rather than adding a lot of sauces like Chinese cuisine does. (Interviewee 18)

In contrast to Chinese respondents who mostly reported neutral or favorable attitudes toward Japan, most Japanese respondents reported neutral or unfavorable views toward China. The aspects they like and dislike about China are similar across all interviewees. What they like can be mainly summarized by (1) Chinese traditional culture, and (2) China's contribution to Japan's economy, such as investment and tourism. What they dislike also relates mainly to two points: (1) the Chinese communist government being aggressive toward Japan, and (2) the bad manners of Chinese people as exemplified by loud and rule-defying tourists.

On the one hand, some of them claimed that "I cannot dislike Chinese culture because Japan built its own culture based on it." On the other hand, it is not uncommon for Japanese respondents to understand the political relationship with China as mutual hatred:

The media often portrays protests against Japan in China. It seems to happen regularly. I remember a year ago, there was a huge protest where Chinese people were crashing Uniqlo and messing up everything.... guess these protests happen either because of WWII or Chinese young people inheriting the mindset of hating Japanese people. (Interviewee 1)

\subsection{Sources of Information: How Do We Know About a Country?}

The 2019 China-Japan Joint Opinion Survey (The Genron NPO, 2019) shows that $14.4 \%$ of 1,000 Japanese respondents have traveled to China, and $20.2 \%$ of 1,597 Chinese respondents have traveled to Japan. Traveling, in general, helps enhance the feeling of closeness toward a country. Chinese respondents who have been to Japan frequently cited their first-hand experiences that involve micro, detailed information of specific settings when asked to comment on Japan:
It is a place where you can go anywhere on foot. Different from China where streets are so wide, traffic is so heavy, and there are so many red lights to wait for, Tokyo is very suitable for walking... sometimes when you walk aimlessly you can see small temples that melt very well with the street scene, different from China's big temples. The street is full of surprises for foreigners like me. (Interviewee 8)

Convenient stores are really convenient. Transportation is also very convenient. The living environment seems really fine. Many things seem to be prepared for individuals, such as individual seats at restaurants, perhaps reflecting a lack of sense of community. But for people like me who may live alone, that's convenient. (Interviewee 6)

Among the 20 Chinese respondents, 15 had never been to Japan, so their sources of information about Japan were also inquired about. The most commonly mentioned source is Japanese pop culture: dramas, anime, and variety shows. The next common source is the introductory articles on popular Chinese social media (such as Weibo, Wechat public account, Zhihu, and Douyin) made by Chinese bloggers or video makers. In a positive tone, these contents mostly portray the beautiful scenery, interesting cultural practices, and popular celebrities in Japan. It is common that these articles excessively idolize Japan to the extent that Chinese tourists might experience disillusion upon seeing the real Japan, as one of the respondents commented,

Some Chinese public intellectuals are really into writing articles that idolize Japan, saying that they have such a wonderful welfare system and they are so clean and self-disciplined. Actually, when I was in Japan, I went to their night markets. Japanese people there showed another side of their personality. Things were dirty and messy. (Interviewee 13)

Other sources of knowledge include official news on Chinese media, conversations with friends who have been to Japan, serious Japanese literature (usually by Murakami Haruki or Watanabe Junichi). The anti-Japan war drama, a TV genre in China that tended to depict WWII in a lighthearted, comical way, had only one mention. In contrast to the common conception that Chinese people mainly take information from governmental or other official channels, the most common sources of knowledge about Japan are apolitical and entertaining, often adopting a positive tone, being produced by either the Japanese pop culture industry itself or Chinese online influencers who mostly hold favorable attitudes toward Japan. In addition, the widespread admiration toward the 'advanced' or 'civilized' aspects of Japan among the Chinese interviewees may also reflect the heavy discourses on the need to improve 'civilian quality' by the socialist state (Chu, 2016). In some way, young Chinese 
are projecting their received notions of idealized nationhood onto Japan and view Japan as a positive model of nation-building. Figure 3 shows the frequencies of different sources of knowledge about Japan that appeared in my interviews with Chinese respondents.

In contrast, Japanese youths mostly understand China via official channels, such as history textbooks and TV news. The textbook mainly introduces about ancient China without much relevance to today, and the news report is often negative:

In Japan, you basically only hear about two things related to China. One is that their patrol aircrafts are lingering around our borders again. I don't know why but it seems they intend to invade or something. Another is the bad manners of Chinese people. Like, oh, some tourists are having serious conflicts with Japanese people somewhere again. It's in the news a lot. (Interviewee 2)

Counterintuitively, given the heavy state control in China, Japanese respondents' source of knowledge toward China is nonetheless more official and limited than that of the Chinese respondents. One reason may be that people in the wealthier, capitalistic parts of the world tend to trust their government more and do not doubt the truthfulness of such coverage (Silver et al., 2019). In addition, while many Chinese youths actively search for information about Japan out of personal interest or curiosity, there seems to be nothing attractive about contemporary Chinese culture that would draw foreigners to dig in by themselves.

\subsection{From Pop to Highbrow}

Most Japanese respondents reported no contact with or memory of Chinese pop culture, being unable to recall even one Chinese drama, movie, or piece of music. Their contact with Chinese pop culture included "the vague memory of hearing some random Chinese song on the street," "a Kungfu movie," and "a documentary about
Chinese traditional culture that teacher showed us in class." When asked to reflect on the lack of contact with Chinese pop culture, many Japanese respondents concluded that the Japanese entertainment market was already saturated and foreign content was generally not needed. Nonetheless, Korean and American pop culture had large fan bases in Japan.

When asked what they thought of at the mention of 'Chinese culture,' all Japanese answered only the highbrow, ancient aspect about China that they had to learn during history lessons at school. This observation further illustrated that contemporary China is not perceived as 'cultured,' so that Japanese respondents had to resort to historical China when asked about Chinese culture.

Even though many Japanese respondents expressed their fondness for Chinese traditional culture, such as by saying, "The Chinese architecture and historical sites are amazing. I think they embody the wisdom of ancient Chinese people." They had no problem reconciling a positive view toward historical China and a negative view toward today's China, since "China fell behind." Therefore, no matter how successful Confucius Institutes become at spreading Chinese traditional values, the world may not necessarily acknowledge China's contemporary values, since people can view the highbrow, cultured part of China as completely separate from today's crude, politicized China, as my Japanese interviewees do.

In stark contrast, at the mention of 'Japanese culture,' all Chinese respondents mentioned some aspect of Japan's contemporary culture, most frequently anime and sometimes fashion. When several Chinese participants mentioned their interest in the serious, highbrow aspects of Japanese culture, all of them claimed that this interest originated from their interest in Japanese pop culture:

My knowledge of Japan proceeds in an antichronological way. I am not interested in their traditional culture. It's my interest in anime that motivates me to trace back to its ancient culture. Many people who want to understand Japan would buy the book

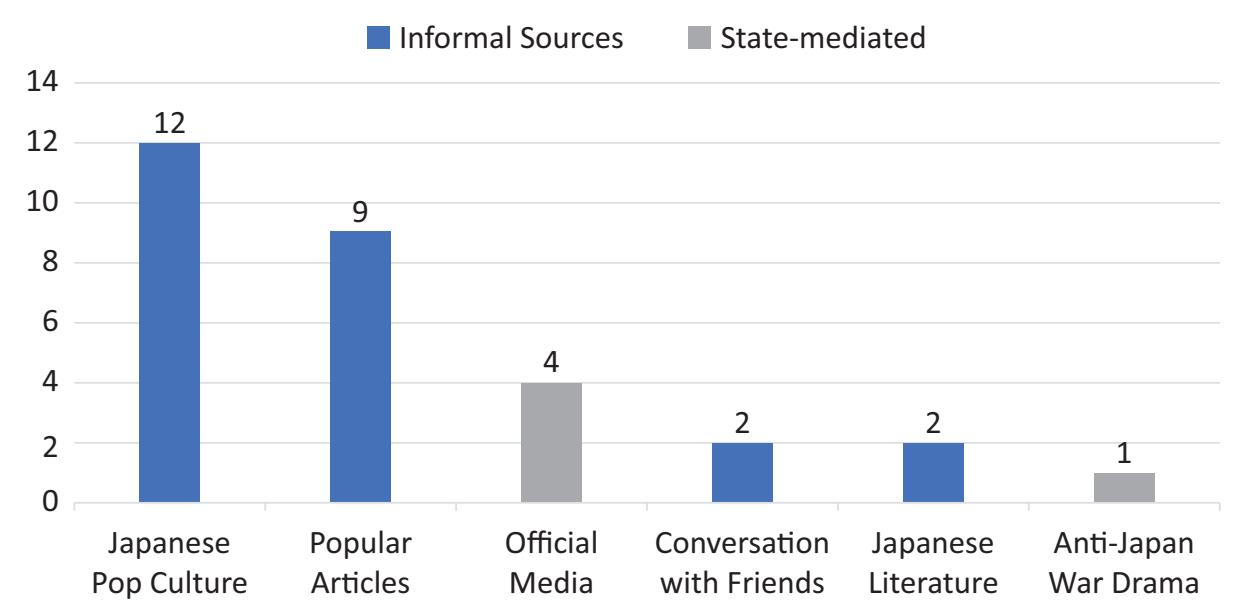

Figure 3. Sources of knowledge: Chinese respondents on Japan. 
The Chrysanthemum and the Sword. I've not even read that book. (Interviewee 3 )

Previously I had neither interests nor opinions on Japanese buildings or arts. I thought ukiyo-e looked strange and their obsession with robots was weird. But later I came to accept and understand all these things because I watched anime so often. (Interviewee 12)

Therefore, pop culture not only creates commercial profit, escapes censorship skepticism, but can also channel foreigners' interests toward the more serious, highbrow aspects of a nation's culture. We cannot help but wonder, what is the charm of Japanese pop culture that attracts the Chinese audience to such an extent?

\subsection{Japanese Pop Culture Appeal Explained}

All of the Chinese respondents were born in the 1990s, a time when Japanese pop culture flourished in Asia (Iwabuchi, 1998). All of the Chinese respondents first got in touch with Japanese anime during primary school, since it was aired by the children's channel of China Central Television (CCTV), a television network officially owned by the PRC State Council. CCTV broadcasted Japanese anime simply for its high quality or profitability, but at the same time, a sense of familiarity with Japanese culture was cultivated. Anime like Digimon, Case Closed, Chibi Maruko-chan, and Doraemon were common childhood memories shared by many Chinese children. Today, even having entered adulthood, my respondents are still passive or active consumers of Japanese pop culture, 'passive' meaning that they frequently get recommendations in the news feed online, and 'active' in the sense that more than half of them actively search for Japanese pop culture on a regular basis: "My impression of Japan is favorable because even though Japan has done bad things in the past, I think my most prominent impression of Japan is anime. It makes me feel a sense of closeness, at least not dislike" (Interviewee 15).

One interviewee, who prefers Korean pop culture to Japanese pop culture because she prefers "real celebrities over fantasy characters," still acknowledges the deep impression left by a childhood anime:

When I was in primary school, I liked to read Inuyasha, where characters could travel across time. The bookstore near my home had manga so I read there every day after school. It's all a precious childhood memory to me. People always feel warm and special to things in their memories. (Interviewee 14)

When Chinese children grow to be adolescents, Japanese pop culture continues to offer attractive content with more explicit depictions of romance, sex, violence, and complicated story plots that Chinese media cannot offer due to either skill inadequacy or strict censorship. The teen dramas were not aired officially, but
Chinese young adults usually had ways to find them on the internet.

Answering "what type of anime do you like to watch," Interviewee 10 replied:

Right now, I like the funny and inspiring ones. When I was a kid, I liked anime about adventures and exploration. When I went to middle school, I liked to watch high school romance. At different stages of your life, you have different preferences, but Japanese anime covers everything. Whatever age you are, they offer so many themes for you to pick from.

Therefore, as a mainstream entertainment for children and a subculture for teens, Japanese pop culture accompanies the growth of Chinese young adults all the way into adulthood, many of whom may carry their passion and fascination into middle-age or beyond. Along the way, Japanese pop culture shapes Chinese young adults' life values and cultivates a strong sense of appreciation for Japan.

When further prompted to explain how the feelings of closeness and curiosity were generated, respondents gave reasons falling into four general categories, ordered from micro to macro:

1. Pleasant psychological effects: "You watch anime to entertain and relax yourself. Just like novels or movies, anime is an effective art form to make you feel good" (Interviewee 15).

2. Aesthetics and relatable narratives: "Japanese anime is really beautiful. Every frame is like a picture.... like the drama Unnatural because the characters in it feel a sense of mission for their careers. I also want to feel a pure sense of passion for my job" (Interviewee 5).

3. Cultural odor: "In dramas and anime, Japanese people are the carriers of plots. Because people are the subjects, or the centers, of the interesting storylines, I grow to like Japanese people and Japan in general" (Interviewee 18).

4. Cultural proximity: "Japan shares many aspects of culture with China. American dramas are too foreign for me, but Japanese dramas contain a satisfying mix of novelty and familiarity" (Interviewee 4).

Cultural odor, a term coined by Iwabuchi (1998), refers to the ability of a cultural product to provoke people's positive associations of the product with the country of origin and its lifestyle. Before the 1990s, when Japan's main overseas exports largely consisted of consumer machinery, Japan was a faceless economic superpower that easily fell prey to a Western Orientalist discourse (Iwabuchi, 1998, p. 165). But after the 1990s, things changed. In addition, some scholars argued that Japanese pop culture was particularly appealing in today's postmodern world (Allison, 2006; Azuma, 2009), where capitalism and advanced technology have led to a sense 
of alienation from the past and loss of community (Allison, 2006). Japanese anime creates fantasy worlds with friendly characters in an age lacking meaningful social contact, with sophisticated plots beyond Disney's simplistic nostalgia (Allison, 2006). The phenomena of Otaku and Hikikomori-people who lock themselves in their rooms for years and seek refuge in the immersive worlds of anime, comics, and games-also grow to be a worrying social issue in Japan (Tamaki, 2013).

\subsection{Views on History: Mechanisms for Reconciling Contradictory Sentiments}

About half of the Chinese respondents expressed unequivocal anger toward Japan's handling of issues relating to WWII. The other half expressed more nuanced attitudes, by (1) separating the present from the past, and (2) separating a nation's behavior from its culture and people:

What happened in the past always happened in a very specific historical context. As I mature, I tend not to see things in black-and-white. (Interviewee 6)

Just like Americans hate the Chinese government but like the small decorations I brought from China, I feel the same toward Japan. (Interviewee 17)

None of the Chinese respondents here ever actively boycotted Japanese goods due to the troubling history or island conflicts. Nonetheless, there had been instances of large-scale boycotting of Japanese goods in China in 2006 and 2013 in response to Japan's textbook controversy and island disputes (Gries et al., 2016; Qiu, 2006). Most interviewees in my sample, however, claimed that product quality was the major concern when they were shopping. As one respondent explained, "When you shop in your daily life, history or international relation does not really pop up in your head, because it's not directly related."

Clearly, the traumatic history was neither forgotten nor denied, but some of my respondents struggled mentally to reconcile the hatred they were 'supposed' to feel and their personal fondness toward Japan. In describing their sentiments, one used the metaphor of "falling in love with your enemy's daughter." In this sense, the cute, contemporary Japan is perceived as connected to but also distinct from the militaristic Japan, as 'his daughter.' Another respondent used the metaphor of "Japan is like your poor neighbor who got rich, and in the process of getting rich, he hurt you." These metaphors reflect a perception of Japan as an 'other,' but at the same time an 'other' that the 'self' feels close to, not only physically (as reflected by 'neighbor') but also mentally (as reflected by 'falling in love').

On the Japanese side, more than half of the respondents reported their lack of any knowledge of what had happened between Japan and China during WWII. A typ- ical response was, "Japan is a perpetrator in the sense that it attacked Pearl Harbor, but it's more like a victim because it was bombed by the US," demonstrating a general understanding of Japan's involvement in WWII as a victim of atomic bombs. Among the respondents who are knowledgeable of Japan's imperialist activities, several thought the Japanese government should apologize, with twice as many thinking that there was no concrete evidence for Japan's violence, or that the current generation shall not bear responsibility for the past. In general, the more historical details a respondent knew about concerning WWII, the more sense of responsibility he or she felt Japan should bear.

An interviewee who had actively researched Japan's war involvement said:

In high school, teachers specifically avoided mentioning the relationship between Japan and China during WWII because it's too problematic. They just dive into the air bombing in Japan and how we were victimized by America. One justification [of the invasion] is that the Japanese military was liberating Asian countries from Western imperialists since Western countries were invading and dividing China....I definitely think that we need a historical narrative acceptable for the Chinese, Korean, and other people victimized by Japan, because it's insane how Japan is denying the responsibility....For the Japanese government there are many things they should do. One is to compensate the victims. That's urgent. We should acknowledge the truth, make an apology, and establish a great educational system so that we don't repeat the same approach again....Some people feel if they learn about the negative things about their country it will affect their sense of identity and pride. But if you want your country to be great in a real sense, your country needs to be just. (Interviewee 4)

But in general, my results corroborate the view that the Japanese educational system failed at properly informing the younger generation of the basic historical facts that occurred during WWII (Qiu, 2006; Schneider, 2008). My data on the Chinese side has also shown that if Japan were able to sincerely reflect on its past wrongdoings, there would be few reasons for Japan to be perceived negatively. Instrumentally, it would also improve Japan's economic and political interests, as it would facilitate better cooperation with neighboring countries.

\section{Conclusion}

While China is a rising hard power in Asia and beyond, the media flow between China and Japan still tends to be one-way, in that China is a heavy importer of Japanese media content. While the Chinese history textbook and anti-Japan war dramas endeavor to pass on the collective memory of WWII, Japanese pop culture exports Japan's own representation of itself as innocuous and appealing. 
As early as the 1920s, when Japan aspired to be an imperial power, it already understood the power of pop culture and media, using them strategically to build support domestically (Iwabuchi, 2002). For example, pictures and narratives of children were used to moralize and humanize war given the assumed purity and innocence of children (Fruhstuck, 2017). Eager to reinvent itself and create a benign image of postwar Japan, since the 1980s, the Japanese Ministry of Foreign Affairs has run the Cool Japan project, using pop culture to build Japan's cool.

People are not mere exercisers of calculation rationality with passively received information but are drawn by a need to feel affect, pleasure, and a sense of solidarity (Alexander et al., 2012). Since pop culture is good at constructing and selling both aesthetics and narratives, many Japanese pop culture symbols have become totems-sources of emotional energy that excite and unite (Collins, 2004; Durkheim, 1995). These symbols have now attained cult status, such as the anime character Hatsune Miku, who inspired 'China's YouTube' Bilibili today. So have the shooting locations of dramas and anime, which continuously draw tourists from all over the world to visit (Lee \& Han, 2013). These pop-culture symbols also contain a strong cultural odor-effectively evoking an affiliative association with Japan itself and a Japanese way of life (Iwabuchi, 1998). Therefore, the sacredness attached to these elements of Japanese pop culture is also successfully transferred to the political entity of Japan itself.

Thus, even though there has been an analytical tradition (such as the Kantian one) to separate the aesthetic and the moral (Kuipers, 2019), my article offers an example where the aesthetic might, to a certain degree, cleanse the moral. As Japan gradually builds its image as a developed, modern country via pop culture (an interesting, relatable dreamland with all the possibilities portrayed in its anime and drama), the image built by the virtual media has, at least in part, countered the sentiments shaped by traumatic historical events. In this process, 'Japan' as constructed by its pop culture acquires its own autonomy different from 'Japan' the political representation; it reshapes the image of Japan, transforming it from the profane (in Chinese historical, collective memory) into the sacred (a modern, fashionable symbol that Chinese youth aspire to).

In contrast, the second largest economy China faces tremendous difficulty presenting itself as benign and trustworthy to the global community (Hartig, 2016). In 2004, China's Ministry of Foreign Affairs established a division of Public Diplomacy to broadcast Chinese political ideologies abroad, especially among developing countries (Thussu et al., 2017). In 2009, the Chinese State Council formally declared culture as a strategic industry, ready to invest 45 million yuan for the state media to run overseas to compete with BBC and CNN (Thussu et al., 2017). But these efforts were not very successful, as foreign audiences were quick to condemn them as propa- ganda (Shambaugh, 2015). While some scholars explain this soft power failure as due to China's fundamental lack of attractive political values (Paradise, 2009), my article nonetheless suggests that developing an attractive pop culture in the entertainment sphere may, counterintuitively, achieve the desired political effect of articulating national values, at least toward the public.

In conclusion, pop culture does not generate power in the conventional sense of authority or dominance (Otmazgin, 2008). With the universal appeal of entertainment and propelled by commerce, pop culture relaxes vigilance, escapes censorship, and bypasses nation-state boundaries to effectively distribute values. Pop culture is often viewed as lowbrow and crude in comparison to highbrow culture, which is arguably consumed by individuals as a means of acquiring status (Bourdieu, 1984; Levine, 1990). Yet in a transnational context, pop culture carries surprising political influences that the Chinese Dream' or Confucius Institutes cannot achieve. Countries that have recognized this point have started to develop sophisticated pop culture industries early on (such as the US, Japan, and South Korea) and have been more successful at building their national image.

In terms of China's national image, we need to note that the data collection of this article was completed before the spread of Covid-19. China aroused a great deal of hostility around the globe as it was perceived to be the country of origin, but also it demonstrated leadership by recovering quickly (Salzberger et al., 2020) and aiding foreign countries (Kurtzer, 2020). Future research should look further into how Covid-19 has changed China's national image and the global dynamics.

\section{Acknowledgments}

I would like to thank my advisors Prof. Jeffrey Alexander and Prof. Phil Smith at Yale University, who offered me a great deal of help and suggestions throughout my writing. I would also like to thank Prof. Vida Bajc, members at the Center for Cultural Sociology, as well as students at the Bootcamp writing class, for their patience and insightful remarks. Finally, I would like to thank the editors and reviewers, whose valuable feedback has greatly helped me improve the article.

\section{Conflict of Interests}

The author declares no conflict of interest.

\section{References}

Alexander, J., Bartmanski, D., \& Giesen, B. (Eds.). (2012). Iconic power: Materiality and meaning in social life. Springer.

Allison, A. (2006). The Japan fad in global young adult culture and millennial capitalism. Mechademia, 1(1), 11-21.

Ang, I., Isar, Y. R., \& Mar, P. (Eds.). (2016). Cultural diplo- 
macy: Beyond the national interest? Routledge.

Avenell, S. (2013). Beyond mimesis-Japan and the uses of political ideology in Singapore. In E. Vickers, N. Shimazu, \& P. Morris (Eds.), Imagining Japan in post-war East Asia: Identity politics, schooling and popular culture (pp. 22-49). Routledge.

Azuma, H. (2009). Otaku: Japan's database animals. University of Minnesota Press.

Belmonte, L. A. (2013). Selling the American way: US propaganda and the Cold War. University of Pennsylvania Press.

Bourdieu, P. (1984). Distinction: A social critique of the judgement of taste. Harvard University Press.

Burney, M., \& Donaldson, A. (2018). Japan: a land of rising soft power. British Council. https://www. britishcouncil.org/research-policy-insight/insightarticles/japan-rising-soft-power

Chu, H. (2016). Looking at core civilian quality from an international perspective and China's position: Improving civilian quality and transforming educational objectives in 21st century China. Jiaoyu Yanjiu, 11, 8-18. http://ex.cssn.cn/jyx/jyx_jxl/201707/ t20170705 3569643.shtml

Collins, R. (2004). Interaction ritual chains. Princeton University Press.

Cronin, A. M. (2018). Public relations capitalism: Promotional culture, publics and commercial democracy. Springer.

Duff, P. A. (2002). The discursive co-construction of knowledge, identity, and difference: An ethnography of communication in the high school mainstream. Applied Linguistics, 23(3), 289-322.

Durkheim, E. (1995). The elementary forms of the religious life. Simon and Schuster.

Fruhstuck, S. (2017). Playing war. University of California Press.

Gries, P. H., Steiger, D., \& Wang, T. (2016). Popular nationalism and China's Japan policy: The Diaoyu Islands protests, 2012-2013. Journal of Contemporary China, 25(98), 264-276.

Gries, P. H., Zhang, Q., Masui, Y., \& Lee, Y. W. (2009). Historical beliefs and the perception of threat in Northeast Asia: Colonialism, the tributary system, and China-Japan-Korea relations in the twenty-first century. International Relations of the Asia-Pacific, 9(2), 245-265.

Hartig, F. (2012). Confucius Institutes and the rise of China. Journal of Chinese Political Science, 17(1), 53-76.

Hartig, F. (2016). How China understands public diplomacy: The importance of national image for national interests. International Studies Review, 18(4), 655-680.

Hayden, C. (2012). The rhetoric of soft power: Public diplomacy in global contexts. Lexington Books.

Holm, M. (2016). Soft power and empire. In N. Dalziel \& J. M. MacKenzie (Eds.), The encyclopedia of empire. https://doi.org/10.1002/9781118455074.wbeoe092
Institute of Curriculum and Textbook. (2009). Eighthgrade Chinese history. People's Education Press.

Iwabuchi, K. (1998). Marketing 'Japan': Japanese cultural presence under a global gaze. Japanese Studies, 18(2), 165-180.

Iwabuchi, K. (2002). "Soft" nationalism and narcissism: Japanese popular culture goes global. Asian Studies Review, 26(4), 447-469.

Kuipers, G. (2019). Cultural narratives and their social supports, or: Sociology as a team sport. The British Journal of Sociology, 70(3), 708.

Kurtzer, J. (2020). China's humanitarian aid: Cooperation amid competition. Center for Strategic and International Studies. https://www.csis.org/analysis/chinashumanitarian-aid-cooperation-amidst-competition

Lee, I. Y., \& Han, C. (2013). Politics, popular culture, and images of Japan in Taiwan. In E. Vickers, N. Shimazu, \& P. Morris (Eds.), Imagining Japan in post-war East Asia: Identity politics, schooling and popular culture (pp. 49-67). Routledge.

Leung, L. Y. M. (2004). Ganbaru and its transcultural audience: Imaginary and reality of Japanese TV dramas in Hong Kong. In K. Iwabuchi (Ed.), Feeling Asian modernities: Transnational consumption of Japanese TV dramas (pp. 89-105). Hong Kong University Press.

Levine, L. W. (1990). Highbrow/lowbrow: The emergence of cultural hierarchy in America. Harvard University Press.

Liu, J., Li, L., \& Chen, Z. (1997). War of resistance against Japan dictionary. Beijing Yanshan Publishing House.

Mattern, J. B. (2005). Why soft power isn't so soft: Representational force and the sociolinguistic construction of attraction in world politics. Millennium, 33(3), 583-612.

May, S. (2019). The power of cute. Princeton University Press.

Ministry of Internal Affairs and Communications. (2018). Basic data of ICT industries. Statistics Bureau of Japan. https://www.soumu.go.jp/johotsusintokei/ whitepaper/ja/h30/pdf/n5100000.pdf

National Bureau of Statistics of China. (2019). China statistical yearbook. China Statistics Press. http://www. stats.gov.cn/tjsj/ndsj/2019/indexeh.htm

Nye, J. S. (1990a). Soft power. Foreign Policy, 80(Autumn), 153-171. https://doi.org/10.2307/ 1148580

Nye, J. S. (1990b). The changing nature of world power. Political Science Quarterly, 105(2), 177-192.

Nye, J. S. (2012). China and soft power. South African Journal of International Affairs, 19(2), 151-155.

Otmazgin, N. K. (2008). Contesting soft power: Japanese popular culture in East and Southeast Asia. International Relations of the Asia-Pacific, 8(1), 73-101.

Paradise, J. F. (2009). China and international harmony: The role of Confucius Institutes in bolstering Beijing's soft power. Asian Survey, 49(4), 647-669.

Qiu, J. (2006). The politics of history and historical memory in China-Japan relations. Journal of Chinese Polit- 
ical Science, 11(1), 25-53.

Salzberger, B., Glück, T., \& Ehrenstein, B. (2020). Successful containment of Covid-19: The WHO-Report on the Covid-19 outbreak in China. Infection, 48, 151-153. https://doi.org/10.1007/s15010-020-01409-4

Schaller, M. (1985). The American occupation of Japan: The origins of the cold war in Asia. Oxford University Press.

Schneider, C. (2008). The Japanese history textbook controversy in East Asian perspective. The Annals of the American Academy of Political and Social Science, 617(1), 107-122.

Shambaugh, D. (2015). China's soft-power push: The search for respect. Foreign Affairs, 94(4), 99-107.

Silver, L., Devlin, K., \& Huang, C. (2019). China's economic growth mostly welcomed in emerging markets, but neighbors wary of its influence: US still seen as World's leading economic power. Pew Research Center. https://www.pewresearch.org/global/2019/ 12/05/chinas-economic-growth-mostly-welcomedin-emerging-markets-but-neighbors-wary-of-itsinfluence

Siriyuvasak, U. (2004). Popular culture and youth consumption: Modernity, identity and social transforma- tion. In K. Iwabuchi (Ed.), Feeling Asian modernities: Transnational consumption of Japanese TV dramas (pp. 177-202). Hong Kong University Press.

Snow, N., \& Taylor, P. M. (2006). The revival of the propaganda state: US propaganda at home and abroad since 9/11. International Communication Gazette, 68(5/6), 389-407.

Sontag, S. (2004). Regarding the pain of others. Penguin. Takeuchi, Y. (1993). Nihon to ajia [Japan to Asia]. Chikuma.

Tamaki, S. (2013). Hikikomori: Adolescence without end. University of Minnesota Press.

Tanaka, S. (1995). Japan's Orient: Rendering pasts into history. University of California Press.

The Genron NPO. (2019). The 15th joint public opinion poll: Japan-China public opinion survey 2019. https:// www.genron-npo.net/en/archives/191024.pdf

Thussu, D. K., De Burgh, H., \& Shi, A. (Eds.). (2017). China's media go global. Routledge.

Ward, T. J., \& Lay, W. D. (2016). The comfort women controversy: Not over yet. East Asia, 33(4), 255-269.

Yueh, H. I. S. (2016). Identity politics and popular culture in Taiwan: A sajiao generation. Lexington Books.

\section{About the Author}

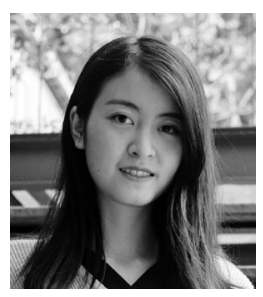

Yuqing $\mathbf{W u}$ is a PhD Candidate in Sociology at Yale University (with a BA from the University of Wisconsin-Madison). She is interested in how media contributes to national soft power in East Asia. 